\title{
Abuse Liability of Baclofen
}

\author{
Samir Kumar Praharaj \\ Department of Psychiatry, Kasturba Medical College, Manipal, Karnataka, India
}

\section{TO THE EDITOR}

I read with interest the case report on baclofen abuse by Ghosh and Bhuyan ${ }^{1)}$ in May issue of Clinincal Psychopharmacology and Neuroscience 2017. The patient reportedly was prescribed quetiapine $100 \mathrm{mg}$, escitalopram $20 \mathrm{mg}$, mirtazapine $15 \mathrm{mg}$, lorazepam $2 \mathrm{mg}$ and baclofen $20 \mathrm{mg}$ after initial detoxification, for depression and insomnia along with relapse prevention. As mentioned, escitalopram was added as depressive symptoms persisted while on mirtazapine. However, it is not clear why mirtazapine was continued when it was ineffective for depression. Similarly, the reason why lorazepam was continued is not clear; it is always advisable to avoid benzodiazepines after the initial detoxification. ${ }^{2)}$ For those with persisting insomnia associated with alcohol dependence several medications are found to be useful, but trazodone has the most data suggesting efficacy.

At follow up, the patient was using high doses of baclofen $80 \mathrm{mg}$ (frequency not mentioned) along with mirtazapine $15 \mathrm{mg}$ and lorazepam $2 \mathrm{mg}$ daily, for the euphorient effects. The duration of the euphoric symptoms after each usage of high dose baclofen is not clear from the report. However, it is quite possible that in this case the combination of baclofen and lorazepam has additive effects, as both are GABA agonists. Combinations of psychotropic drugs for higher euphoric effect has been reported before. $^{4)}$

The authors assert that baclofen abuse has not been reported before. Perry et al. ${ }^{5)}$ in 1998 first reported baclofen abuse by 14 adolescents during a party where they con-

Received: June 20, 2017 / Accepted: June 21, 2017

Address for correspondence: Samir Kumar Praharaj, MBBS, $\mathrm{MD}$, DPM

Department of Psychiatry, Kasturba Medical College, Manipal, Karnataka 5760104, India

Tel: +91-8971026304, Fax: +91-820-2571930

E-mail: samirpsyche@yahoo.co.in sumed between 60 to $600 \mathrm{mg}$ of baclofen and presented with toxicity symptoms; however, the euphoric effects were not described. Nasti and Brakoulias ${ }^{6}$ have reported baclofen abuse up to $75 \mathrm{mg} /$ day in a 61-year-old lady, who presented with delirium after abrupt discontinuation. Kamal et al. ${ }^{7}$ have reported baclofen abuse up to $80 \mathrm{mg}$ with gamma-hydroxybutyrate (GHB) for sedative and anxiogenic effects, which resulted in fatal overdose. In a case study from India by Das et al..$^{8}$ a 24-year-old male abused baclofen up to $600 \mathrm{mg} /$ day with euphorient effects.

Baclofen is predominantly a selective GABA-B agonist, but at higher doses it may lose selectivity for GABA-B. Also, baclofen has structural homology with GHB, another GABA-B agonist with high abuse potential and is illicitly used as a party-drug. It is postulated that abuse liability of GHB in contrast to baclofen could be because of different receptor subtype of GABA-B. ${ }^{9)}$ However, such selectivity may be lost with higher doses of baclofen leading to euphorient effects.

\section{REFERENCES}

1. Ghosh S, Bhuyan D. Baclofen abuse due to its hypomanic effect in patients with alcohol dependence and comorbid major depressive disorder. Clin Psychopharmacol Neurosci 2017; 15:187-189.

2. DuPont RL. "Should patients with substance use disorders be prescribed benzodiazepines?" No. J Addict Med 2017;11: 84-86.

3. Kolla BP, Mansukhani MP, Schneekloth T. Pharmacological treatment of insomnia in alcohol recovery: a systematic review. Alcohol Alcohol 2011;46:578-585.

4. Sarkhel S, Praharaj SK, Sinha VK. Does lizard tail lacing heighten cannabis addiction? Am J Addict 2011;20:181.

5. Perry HE, Wright RO, Shannon MW, Woolf AD. Baclofen overdose: drug experimentation in a group of adolescents. Pediatrics 1998;101:1045-1048.

6. Nasti JJ, Brakoulias V. Chronic baclofen abuse and withdrawal delirium. Aust N ZJ Psychiatry 2011;45:86-87.

(c) This is an Open-Access article distributed under the terms of the Creative Commons Attribution Non-Commercial License (http://creativecommons.org/licenses/by-nc/4.0) which permits unrestricted non-commercial use, distribution, and reproduction in any medium, provided the original work is properly cited. 
7. Kamal RM, Qurishi R, De Jong CA. Baclofen and $\gamma$-hydroxybutyrate $(G H B)$, a dangerous combination. I Addict Med 2015;9:75-77.

8. Das S, Palappalllil DS, Purushothaman ST, Rajan V. An un- usual case of baclofen abuse. Indian J Psychol Med 2016; $38: 475-476$

9. Carter LP, Koek W, France CP. Behavioral analyses of GHB: receptor mechanisms. Pharmacol Ther 2009;121:100-114. 